\title{
微振動下の内力分布推定に基づいた鋼構造柱梁接合部の健全性評価 INTEGRITY ASSESSMENT OF STEEL BEAM-COLUMN CONNECTIONS USING AMBIENT-BASED INNER-FORCE ESTIMATES
}

\author{
倉田真宏*, 鈴木明子**, 峰岸 楓***, 中島正 愛**** \\ Masahiro KURATA, Akiko SUZUKI, Kaede MINEGISHI \\ and Masayoshi NAKASHIMA
}

\begin{abstract}
This paper presents a method of evaluating local damage in steel beam-column connections using dynamic strain responses measured under ambient vibrations. In the proposed method, inner-force distribution in steel beam-column connection was estimated using the natural modal components measured by PolyVinylidene DiFluoride (PVDF) strain sensors. For evaluating damage in steel beam-column connections, two kinds of damage-related features were proposed. One was the transition of the neutral axis for evaluating the loss of composite action between steel beams and concrete floor slab. The other was the reduction of the dynamic strain responses from the undamaged condition in terms of root mean square (RMS) for quantifying steel beam fractures. A unique testing method was developed to verify the damage-related features at component-level. In the test configuration, the specimen was damaged quasi-statically, and vibration tests were conducted as damage proceeds. Moreover, an analysis model of the specimen was built and updated using dynamic strain responses. This model-updating was particularly interested as it provided estimates on the residual seismic capacities of the specimens in terms of the quantities familiar to structural engineers (i.e., stiffness and strength).
\end{abstract}

Keywords : Structural health monitoring,Beam-column connection, Damage quantification, Vibration test 構造ヘルスモニタリング，柱梁接合部，損傷定量化，振動試験

\section{1 はじめに}

東日本の広域に渡り強い地震動が観測された平成 23 年東北地方 太平洋沖地震は, 未曽有の人的・物的被害をもたらし, 95,000 戸以 上に及ぶ膨大な数の建物に対して, 被災後の安全性が疑われた ${ }^{1)}$. この震災を端緒として, 今後発生が予想される首都圈直下地震や南 海トラフ巨大地震に備え, 被災建物の利用再開までの意思決定を支 援する，健全性評価手法の確立は焦眉の課題である。

被災建物の健全性は，安全限界状態に対する余裕度として評価で きるが, 現段階では具体的な数值として示寸指標に欠け, その客観 的診断は困難である. 地震によって構造部材に生じた損傷を同定し, それに起因寸る剛性や耐力の低下度といった建物の残余耐震性能を 定量的に評価することができれば，余震等により崩壊に至るまでの 余裕度を推定することが可能である.

鋼骨組の場合，被った変形量によって主に損傷が進行する部材が 異なることが知られている．18層鋼骨組のE-defense実験の報告2) では，その損傷は，引張力を受けて生じる床スラブの初期ひび割れ が変形の増大に伴って次第に進展した後, 大変形領域に至ると, 鋼
梁の破断や最下層柱の塑性化が生じるという過程を得ている，床ス ラブ付き実大柱梁接合部試験体を用いて床スラブと鋼梁の損傷度と 振動特性の関連性を調べた研究 ${ }^{3}$ は, 柱梁接合部の水平剛性や接合 部単体の振動特性に与える床スラブ損傷の影響は顕著で, 鋼梁端部 の破断が与える影響度に相当すると報告している．鋼梁の破断は特 定層への変形集中を招くため, 床スラブの損傷に比べて建物の耐力 劣化一の寄与が一層大きく, 崩壊にいたる致命的な損傷となりか补 ない. しかしながら, 水平剛性や振動特性の変化からだけでは, そ れらを区別して評価することは難しい．

被災建物の健全性をすばやく評価する仕組みとして，建物に事前 に設置したセンサの情報を利用する構造ヘルスモニタリング技術が 注目されている.これまでにも, 構造物の固有振動数, モード形状 や伝播波特性といった振動特性の変化により損傷した層の剛性低下 を推定する手法4)-7)や, 建物各階分に設置した加速度記録を用いて建 物を等価1質点系に置き換えたときの履歴特性を基に被害程度を評 価する手法8) が提案されている. これらは, 建物内や各層の床スラ

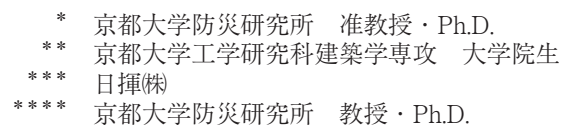

**** 京都大学防災研究所 教授 $\cdot P h . D$

Assoc. Prof., Ph.D., DPRI, Kyoto Univ.

Grad. Stud. Researcher, Dept. of Archi. and Archi.Eng., Kyoto Univ.

JGC Corporation

Prof., Ph.D., DPRI, Kyoto Univ. 
ブや鋼梁の損傷をすべて含む総合的な評価法である. より局所的な 部材レベルの損傷を評価する手法として, 例えば, 加速度応答を用 いて建物モデルを更新し部材の損傷度を推定寸る手法9)や, 卓越振 動モード下の骨組内曲げモーメント分布を動ひずみ応答から推定し, その変化から梁端部の破断量を定量化する手法10) 11), 柱梁接合部周 りの静ひずみ応答分布の変化から影響度マトリックスを用いて損傷 を検知する手法12) 13)などが提案されている. 被る変形によって進行 度が異なる複数の損傷の種類や位置・程度の把握を目的としたとき には，損傷位置近傍に直接センサを設置する後者が有効である。さ らに, 実測データに基づいて同定された損傷状態を反映するように, 床スラブや鋼梁などの損傷部位ごとに解析モデルを更新することで, 被災建物の残余耐震性能の推定精度の向上が期待できる.

このような既往研究を背景として, 本研究では, 鋼構造建物床ス ラブ付き柱梁接合部を対象に, 床スラブのひび割れに伴う合成効果 の低下や鋼梁の破断に起因寸る内力分布の変化に着目し，これら 2 つの損傷度を独立して評価することを目指す，床スラブの合成効果 に対しては，微動下の動ひずみ応答から同定した中立軸を指標とし て新たに提案する．鋼梁の破断に対しては，破断面の曲げ岡性低下 に起因する動ひずみ応答の低下度を利用する手法 10)11)を用いる.さ らに, 上記の損傷指標の変化を解析モデルに反映し, 更新したモデ ルを利用して残余耐震性能を評価する手法を新たに提案し, 実験的 に検証する.

\section{2 柱梁接合部損傷同定振動試験}

\section{1 実験概要}

提案する手法は, 床スラブ付き鋼構造建物内の損傷を受けやすい 部材において常時微振動下の動ひずみ応答を計測し, 地震前後の応 答を比較することにより, 部材レベルの損傷度を推定する. 本手法 の検証には，(1）地震によって構造部材に生じる損傷の再現，(2) 常時微動下で振動する部分構造の挙動の再現, の 2 つの条件を満た 寸実験環境が必要となる。これらの条件下での検証は, 多層多スパ ン骨組を用いた振動台実験などの手法により可能だが，必要とされ る設備・費用を考慮すると, 度重なる検証は困難である。以上を踏 まえて本章では, 次章で提案する損傷指標の実験的検証に先立ち, 固有振動モードが卓越して建物が振動している状態（以下では建物 固有振動モード）にある柱梁接合部の挙動を簡易的に再現する実験 手法を提案する.

\section{2 試験装置及び試験体}

図 1a は, 建物の部分構造の 1 質点系への置換を示している. 同 図中央のように, 部分構造の常時微動を観測すれば, 建物固有振動 モードに対応する振動成分が卓越して存在する. この卓越する振動 成分を実験室内で評価することを考える. 具体的には, 同図右のよ うに, 付加質量を与えた部分構造の 1 質点系モデルを考える. この モデルの振動数を建物の固有振動数に合わせることで, 地震により 発生する破断などの局所損傷に起因する建物固有振動モード下の部 分構造の内力分布の変化を, 簡易な装置により実験的に評価するこ とが可能である。

図 $1 \mathrm{~b}$ に試験装置の全体図を示す，本実験では中層鋼構造建物を 検証対象とし, その部分構造として, 十字型柱梁接合部試験体（詳 細は次節）を採用した。系全体において試験体のみが外力に抵抗す
るように，両端ピン接合のトラス材を用いて試験体の柱頂部とピン 架構の柱中央を結合した。ピン架構上には付加質量を載せ，系全体 の固有周期が一般的な中層鋼構造建物の 1 次固有周期である $0.85 \mathrm{~Hz}$ に相当するように, $1.7 \mathrm{~Hz}$ 付近に調節した. このとき, 付加 質量は約 $4,000 \mathrm{~kg}$ であった。この装置を用いて，(1)この系全体に 水平力を作用させ，地震により発生する破断などの局所損傷を再現 する準静的載荷試験と，（2）系全体を振動させ，建物固有振動モ一 ドを励起する動的載荷試験を, 試験体の終局状態まで交互に繰り返 すことで, 内力分布の変化を追跡する (各手順の詳細は後述).

本試験で用いた試験体の材料特性（降伏応力 $\sigma_{y}$, 最大応力 $\sigma_{u}$, 圧 縮強度 $f_{c}$ ）および寸法を表 1 と図 2 にそれぞれ示す. 床スラブのひ び割れ，鋼梁の破断が振動に起因寸る内力の分布に与える影響をそ れぞれ検討するため, 床スラブの有無をパラメータとした試験体 2 体（A：無，B：有）を用意した。試験体の柱高さは $1,000 \mathrm{~mm}$, 梁 スパン長さは $2,000 \mathrm{~mm}$ であり，実大に対する縮尺は $1 / 4$ である. 梁の材軸方向を $\mathrm{X}$ 軸, 柱高さ方向を $\mathrm{Y}$ 軸と定義する. 試験体の柱に は角型鋼管（ $\square-100 \times 100 \times 9, \mathrm{SM} 490)$ を，梁には H 型鋼（H-100 $\times 60 \times 6 \times 8, \mathrm{SS} 400)$ を用い, 通しダイアフラム形式により接合し た。 また, 梁端は従来型スカラップ形式とした。 床スラブ付き試験 体では, メッシュ筋を配した床スラブ $(2,000 \mathrm{~mm} \times 500 \mathrm{~mm} \times 50 \mathrm{~mm})$ を打設し, 頭付きスタッドの代用として $40 \mathrm{~mm}$ 間隔に溶接した軸径 $6 \mathrm{~mm}$, 高さ $20 \mathrm{~mm}$ の六角ボルトを用いて, 完全合成梁とした。

\section{3 動的載荷試験および計測計画}

準静的載荷試験において柱梁接合部試験体に顕著な損傷が確認さ
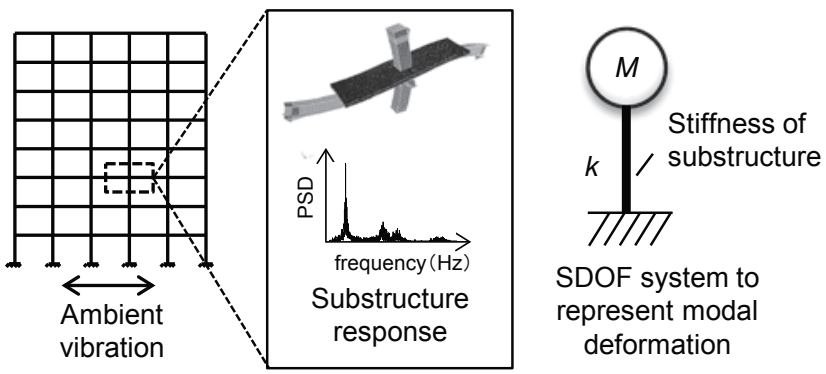

SDOF system to represent modal deformation

(a) Response under ambient vibration and equivalent SDOF system for substructure

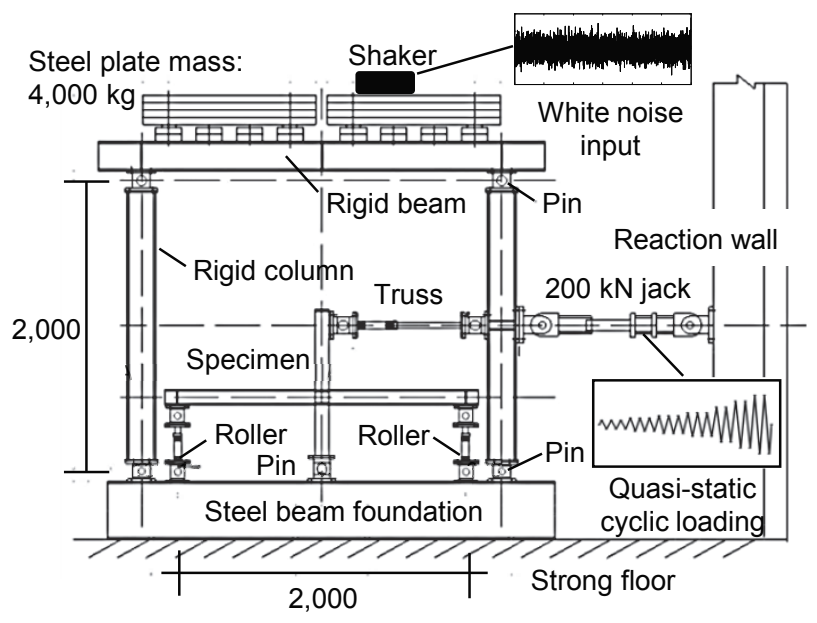

(b) Test setup (Unit: $\mathrm{mm}$ )

Fig. 1 Concept and test system. 
れたサイクル後に, 内力分布の変化により損傷を同定する動的載荷 試験を行った. 動的載荷試験においては, 初期位置で除荷した状態 でジャッキを取り外し, 付加質量上に固定した小型加振機 (APS 113, APS Dynamics）のDC 変位制御により, 水平方向の微振動を加え ることで, 系全体の固有振動を励起した. なお, 風振動・交通振動 などの影響が少ない実験室内環境では, 常時微動下での固有振動を 十分に励起できないことから, 小型加振機を用いて周波数帯域 $0.5 \sim 40 \mathrm{~Hz}$ のホワイトノイズを入力した.

試験体の計測には加速度センサと動ひずみセンサを使用し（図 3)， 無線通信モジュール NARADA (Civionics, LLC) を介して, 各ユ ニットからデータを無線受信した。通信プロトコルは IEEE 802.15.4 準拠のZigbee で, $2.4 \mathrm{GHz}$ の帯域を使用しており, 毎秒約 1,500 ポイントのデータを送信できる. サンプリング周波数及び計 測時間はこれに基づいて決定し，それぞれ $100 \mathrm{~Hz} ， 150$ 秒とした。 加速度計測には, MEMS 型の加速度センサ（Silicon Design, Inc., 012-002）を使用した. 各梁の下フランジに 3 つずつ設置した $\mathrm{AC} 1 \sim \mathrm{AC} 6$ により, 梁の鉛直加速度を計測し, 試験体の固有振動数 やモード形状の推定に用いた。 また柱頂部に設置した AC7 により, 試験体の水平加速度を計測した。使用した加速度計の測定範囲は $\pm 2 \mathrm{~g}$, 感度は $2000 \mathrm{mV} / \mathrm{g}$, 周波数特性は $\mathrm{DC} \sim 300 \mathrm{~Hz}$, ノイズフロア は, $13 \mu \mathrm{g} /(\operatorname{root~Hz})$ である. 動ひずみ計測には, DT1-028K 型（株 式会社東京センサ）の PVDF (Poly Vinylidene Di Fluoride) ピエ ゾフィルムを使用した。標準設定では, $1 \mu \varepsilon$ の動ひずみで, $12 \mathrm{mV}$ の電圧が生じ, 周波数特性は $0.001 \mathrm{~Hz}$ 数 $\mathrm{MHz}$ である. 計測位置と して局所損傷によるひずみの再分配の影響を受けない位置を選択し 11), P1 と P2 位置では梁の上下フランジに, P3 位置では柱両側に 動ひずみセンサを貼付け, 材軸方向の動ひずみ応答を計測した。 な お, P1 と P2 位置ではウェブを中心に $2 つ$ンりサを対称に配置し, 両センサの平均值を応答值として用いた. この操作により, 破断に よる梁のねじれ応答の影響や, 面外変形の影響を取り除いた。

\section{4 無損傷時の振動特性による実験装置の検証}

無損傷時に試験体の初期振動特性を計測し, 提案する実験装置の 特性を検証した. 柱頂部の水平加速度応答 (AC7) の RMS（Root mean square）值により求めた微振動時の入力加速度は, 床スラブ なし試験体，床スラブ付き試験体でそれぞれ $0.013 \mathrm{~m} / \mathrm{s}^{2}, 0.024 \mathrm{~m} / \mathrm{s}^{2}$ であった。 また両試験体ともに, AC1 AC6 位置で計測した加速度 応答により推定した梁のモード形状は, 左右の梁で点対称となって おり, 中層建物が 1 次固有振動モードで層間変形を受けた場合の梁 の曲げ変形が再現できていた. P1 位置で無損傷時に計測した梁下フ ランジにおける動ひずみ応答の RMS 值は, 床スラブなし試験体,

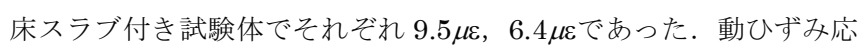
答によるパワースペクトル PSD のピークは床スラブなし試験体, 床スラブ付き試験体でそれぞれ $1.63 \mathrm{~Hz}, 1.83 \mathrm{~Hz}$ に明瞭に現れてお り, 本論で想定した中層建物の固有振動数とほぼ一致した.

\section{5 準静的載荷計画と大変形領域までの挙動}

地震による損傷を再現する準静的載荷試験では, 反力壁に固定さ れた油圧ジャッキをピン支持架構柱の中央にボルト接合し, 水平ジ ヤッキ, 油圧ポンプ, およびコントローラーで構成される載荷シス テムを用いた，柱頂部の水平変位を柱高さで除した層間変形角を漸 増させ, 各ステップ 2 サイクルの正負繰返し載荷を行い, 柱梁接合
部試験体の損傷を進行させた。試験体に顕著な損傷が確認された載 荷サイクル後には, ジャッキを取り外して一旦載荷を中断し，上記 で述べた動的載荷試験に移行する. その後再び載荷を継続し, 終局 状態に至るまで載荷を繰り返した。終局状態では, 試験装置内のピ ン治具の可動限界で 2 サイクルの漸増載荷を止め, 鋼梁に破断が生 じたサイクルでの層間変形角を最大とし, サイクル数を増やすこと によって損傷を進行させた.

2 体の試験体の履歴挙動を図 4 に示寸. 床スラブなし試験体では, 層間変形角 $\theta=0.5 \%, 1.0 \%, 2.0 \%, 3.0 \%, 4.0 \%, 5.0 \%$ までの各ステ ップにおいて 2 回の繰返し載荷を行った後, $8.0 \%$ の正負載荷を繰返 した. 試験体は層間変形角 $1.5 \%$ で降伏し, 耐力や剛性の低下は, 梁 端部の延性亀裂発生後に確認された。 $8.0 \%$ (層間変形角を降伏回転 角で除した塑性率では $\mu=5.3)$ の 1 周目で梁の X 軸負側の梁端部下 フランジのスカラップ底から延性亀裂が入り, 2 周目で同位置下フ

Table 1 Material properties.

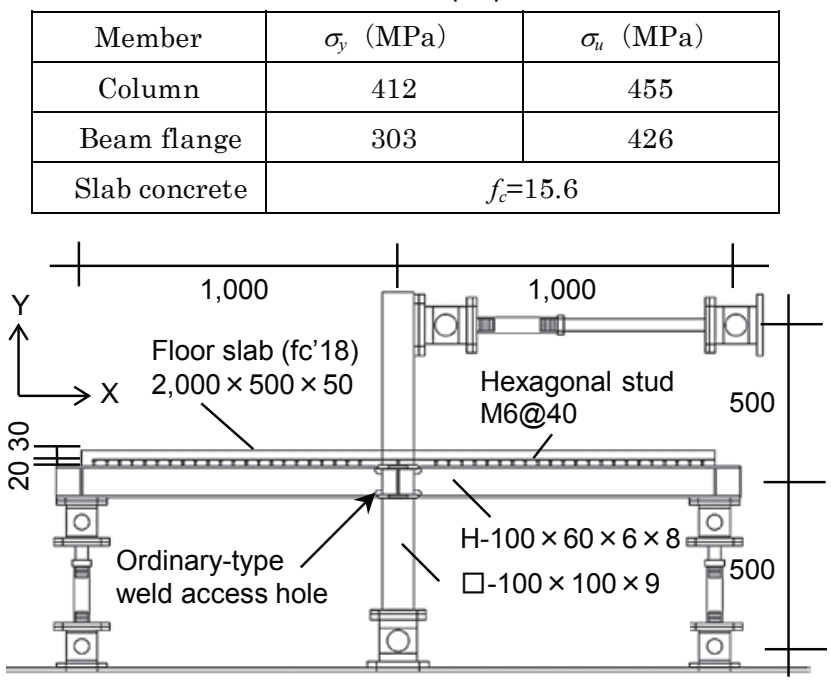

Fig. 2 Specimen (Unit: $\mathrm{mm}$ ).

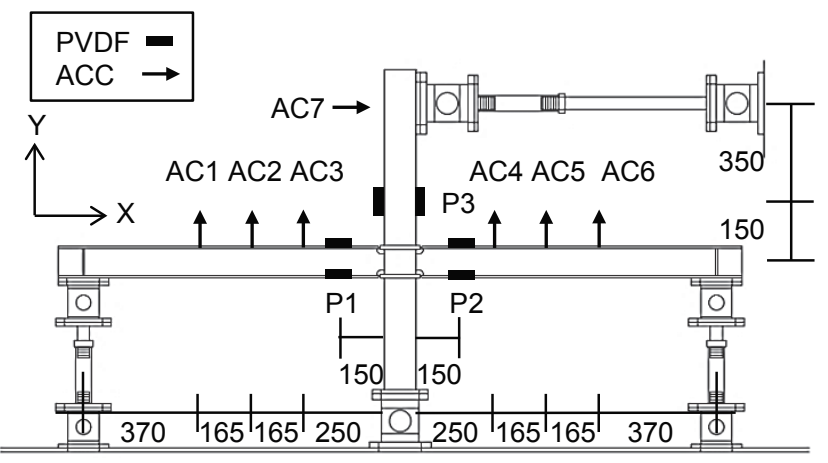

Fig. 3 Sensor layout (Unit: $\mathrm{mm}$ ).

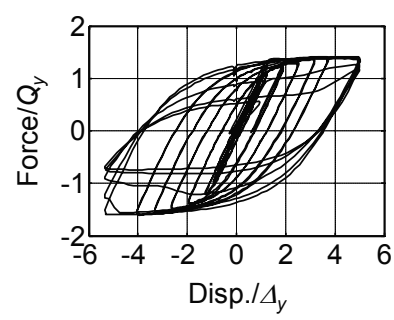

(a) No slab

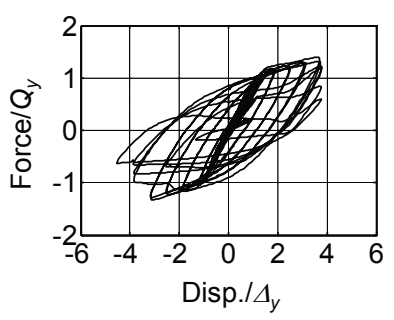

(b) With slab
Fig. 4 Hysteresis loop. 
Table 2 Damage case definition.

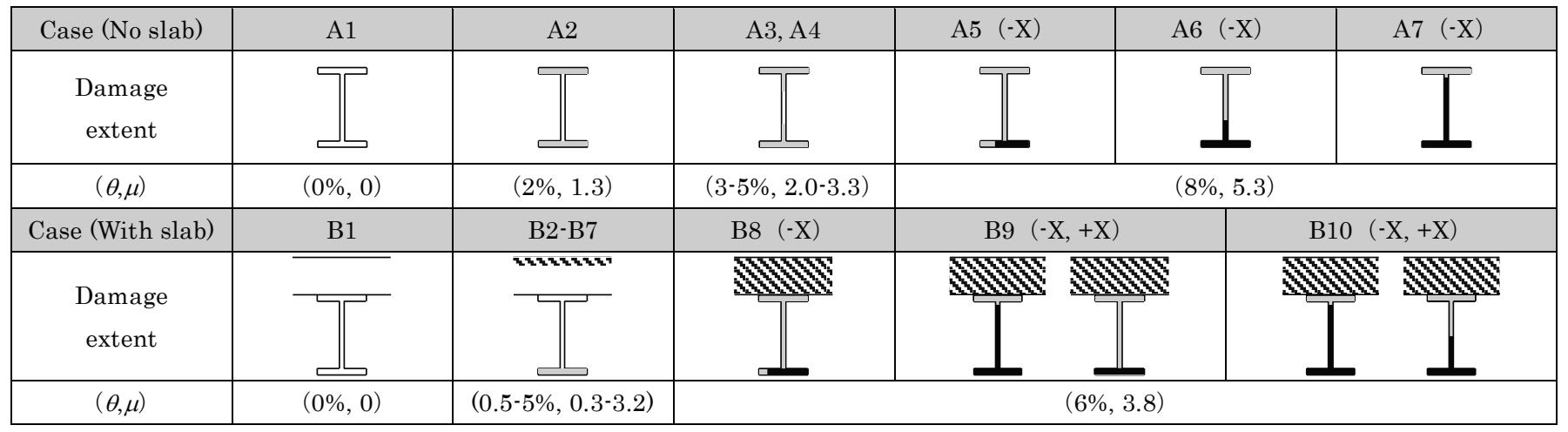

ランジ $2 / 3$ が破断した。さらに 3 周目で同位置下フランジが完全に 破断するとともに, 同位置ウェブの $1 / 3$ が破断した。 その後 5 周目 では同位置ウェブの破断が進行して破断長さがウェブの $90 \%$ にま で至り, 実験を終了した。 以上の損傷観察結果に基づいて, 表 2 に 示す全 7 ケースを定義した. 無損傷時を Case A1 とし, 鋼梁降伏後 を $\mathrm{A} 2$, 梁端部の塑性ヒンジ形成後を $\mathrm{A} 3, \mathrm{~A} 4$, 梁 X 軸負側 $(-\mathrm{X})$ 下フランジ破断後を A 5 ，負側全下フランジとウェブ $1 / 3$ 破断後を $\mathrm{A} 6$ ，負側全下フランジと全ウェブ破断後を $\mathrm{A} 7$ とした.

一方, 床スラブ付き試験体では, 層間変形角 $\theta=0.25 \%, 0.5 \%, 1.0 \%$, $1.5 \%, 2.0 \% ， 3.0 \% ， 4.0 \% ， 5.0 \%$ までの各ステップにおいて 2 回の 繰返し載荷を行った後, $6.0 \%$ の正負載荷を繰返した. 微小変形領域 において, 床スラブは柱面からの圧縮力を受け, 柱の周りに細かい ひび割れや梁直交方向のひび割れが入り始めた，層間変形角 $0.5 \%$ では，梁直交方向のひび割れが進展し，1.0\%から $3.0 \%$ にいて， ひび割れは梁直交・材軸方向ともに梁全長に渡って進展・深長して いった. 3.0\%以降では, 顕著なひび割れが進行することはなく, 柱 まわりに細かいひび割れが進展した. 鋼梁は層間変形角 $1.8 \%$ で降伏 し, $5.0 \%(\mu=3.2)$ の 2 周目において延性亀裂が生じて破断に至っ た. $6.0 \%(\mu=3.8)$ の 1 周目で X 軸負側の接合部付近の梁下フラン ジの $4 / 5$ が破断した. 4 周目で正側の梁下フランジのスカラップ付 近に亀裂が見られたため, 負側の強制変位を増やすことで損傷を進 行させ， 5 周目の負側載荷時に完全に破断した。 その後 6 周目で正 側ウェブ $1 / 2$ が破断し, 実験を終了した. 以上の損傷観察結果に基 づき，表 2 に示寸全 10 ケースを定義した。無損傷時を Case B1, 床スラブの損傷のみが進行するケースを B2 B7（B7 では床スラブ なし試験体と水平剛性がほぼ一致したことから, 合成効果が完全に 失われたと判断し, 床スラブ完全損傷時として定義した), 梁 $\mathrm{X}$ 軸 負側 $(-\mathrm{X})$ 下フランジ破断後を B8, 負側全下フランジとウェブ及 び正側 $(+\mathrm{X})$ 下フランジ破断後を B 9 , 正側ウェブ $1 / 2$ 破断後を B10 とした.

\section{3 内力分布に基づく損傷指標の変化}

合成梁における床スラブと鋼梁の損傷は，局所的な内力の分布に 大きく影響する. 本章では, 実験で観察されたこれら 2 種類の損傷 と相関性の高い損傷指標として, 床スラブひび割れに伴う合成効果 の低下に対しては, 床スラブの圧縮力負担度によって遷移する中立 軸位置を, 鋼梁の破断に対しては, 破断面の曲げ剛性低下に起因す る動ひずみ応答の低下度をそれぞれ抽出した。

\section{1 床スラブの損傷 : 中立軸の変化}

Sigurdardottir 等の研究 ${ }^{14)}$ は, 床スラブと鋼梁の合成効果の減少 に起因する梁断面内の中立軸位置の変化が，床スラブひび割れの損 傷推定に有効であると報告している．床スラブが圧縮力を負担する 正曲げ時の中立軸位置は，スラブの有効幅を仮定すれば，梁の断面 形状により算出される ${ }^{15)}$. 負曲げ時には床スラブは引張力を負担し ないと仮定すると，上下に対称な $\mathrm{H}$ 型断面では，負曲げ時の中立軸 は鋼梁断面中央に位置する.

骨組内の梁が微振動下で動曲げモーメントを受ける時，i次振動 モード下における中立軸位置は, 鋼梁の上下フランジの動ひずみ応 答比から推定でき，その值は交互に現れる正曲げ・負曲げ時の中立 軸の時間平均に相当すると考えられる.ここで梁せい $H$ の合成梁に 対し, 梁断面中央を基準とした $i$ 次振動モード下の動的中立軸位置 $N A$ は, 上下フランジの動ひずみ応答 $\varepsilon_{\text {top }}^{i}, \varepsilon_{\text {bottom }}^{i}$ の RMS 值の比率から, 式（1）で計算できる.

$$
N A=\left(\frac{1}{2}-\frac{\left(\varepsilon_{\text {top }}^{i}\right)_{R M S}}{\left(\varepsilon_{\text {top }}^{i}\right)_{R M S}+\left(\varepsilon_{\text {bottom }}^{i}\right)_{R M S}}\right) H \quad \text { 式 (1) }
$$

床スラブのひび割れによる合成効果の低下に従って，正曲げ時の 中立軸位置が梁中央位置に遷移することから, 地震前後の動的中立 軸位置 $N A$ を評価することで床スラブの損傷度が推定できる．本実 験では, 動的中立軸位置 $N A$ の遷移を追跡するとともに, その遷移 過程を準静的載荷下での中立軸位置との関係性から明らかにした. なお動的中立軸位置の推定には，動ひずみの実測データに対して， 1 次固有振動数 $f_{1}$ を中心とした $0.1 f_{1} \mathrm{~Hz}$ の Butterworth バンドパス フィルタを施し，得られた時刻歴応答の RMS 值を式 (1) に適用し た。一方で準静的載荷下での中立軸位置は，同断面（P1 及び $\mathrm{P} 2)$ の上下フランジの静ひずみ応答から推定した．計測には弾性ひずみ ゲージ（東京測器）を用い, 弾性域応答から推定される中立軸の平 均值をとった.

床スラブ付き試験体における計測位置 $\mathrm{P} 1, \mathrm{P} 2$ の梁が準静的載荷 下で正曲げと負曲げをそれぞれ受けたときの中立軸位置と，1 次振 動モード下での動的中立軸位置 $N A$ を図 5 にそれぞれ示す。座標は 鋼梁断面に対応し, 0 は鋼梁断面の中央位置, \pm 0.5 は上下フランジ 縁に対応する. 準静的載荷正曲げ時の中立軸は, 無損傷時から Case B2 の間で P1，P2 ともに 11\%低下し，ひび割れの進展に伴って床 スラブ側から鋼梁断面の中心位置へ段階的に遷移した. 一方微振動 時では，無損傷時から B2 の間で P1 と P2 でそれぞれ $72 \% ， 48 \%$ 低 下，B5 でそれぞれ $87 \% ， 88 \%$ 低下し，合成効果の低下が顕著に現 

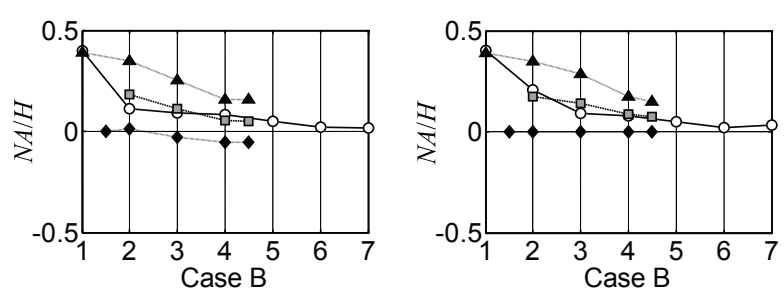

-0-Dynamic $\rightarrow-$ Static pos.

$\rightarrow$ Static ave. $\rightarrow$ Static neg.

(a) P1

(b) P2

Fig. 5 Transition of neutral axis.

われた。微振動下における中立軸は, 正曲げ時と負曲げ時の中立軸の 平均とほぼ一致した結果を示し, その誤差は $1 \%$ 7\%に留まった. ただ し, 床スラブに初期ひび割れが生じていない無損傷状態の B1 におい ては, 床スラブが引張力にも寄与し, 正曲げ時と負曲げ時の平均に相当 せず，正曲げ時の中立軸とほぼ一致している。

\section{2 動ひずみ分布の変化}

常時微動下の建物の応答には, 建物固有振動モードが卓越する振 動成分として含まれている. ここで, 建物固有振動モードの等価静 的外力を考えれば, モード形状の変化が小さい線形構造物に対して は, 等価静的外力下での曲げモーメント分布は構造物の各部材の剛 性比によって一意に決定される. 倉田等は, 微小振動下の鋼部材の 動ひずみ応答の低下度から部材の損傷により局所的に変化する曲げ モーメント分布を推定することで, 梁部材の損傷度（破断面の曲げ 剛性の低下率）を評価した 10) 11)。この手法では, 無損傷部材と損傷 部材に生じる動ひずみ応答の低下度に着目した損傷指標 $S D$ を式 (2) で定義している.ここでは, 損傷の進展に伴い, 微振動下での動ひ ずみ比が曲げモーメント比に対応して変化すると仮定している.

$$
S D=\frac{R_{d}^{i}-R^{i}}{R^{i}}, \quad R^{i}=\frac{\left(\varepsilon_{\text {beam }}^{i}\right)_{R M S}}{\left(\varepsilon_{\text {reference }}^{i}\right)_{R M S}}
$$

ここで $R^{i}$ は建物内のある 2 点間（例えば損傷を観察する梁とリファ レンスとする柱)の動ひずみ応答 $\varepsilon_{\text {beam }}^{i}, \varepsilon_{\text {reference }}^{i}$ の RMS 值の比であり, 構造物が線形であれば外力の大きさに依存しない. リファレンス柱 が無損傷であれば, 損傷を受けた梁の損傷指標 $S D$ は, 無損傷時の 比 $R^{i}$ を基準としたときの損傷時の比 $R_{d}^{i}$ への変化率として表現され, 損傷による部材剛性の変化を表す.

骨組全体の計測においては, 事前の解析において損傷が軽微な層 （例えば，最上階付近）の柱をリファレンスとすることで, 式 (2) において, 損傷した部材とリファレンスとなる無損傷の部材の部材 剛性比の変化を追跡できる. しかしながら, 部分構造を対象とした 本実験では試験体内の全ての部材が損傷の影響を受ける，そこで, 準静的試験を開始する前の無損傷時と準静的載荷開始後の損傷時の 曲げモーメント分布を比較する. 本実験のために修正した損傷指標 莐を，式（3）に定義する.

$$
\widetilde{S D}=\frac{\left(k_{d} / k\right) \cdot R_{d}^{i}-R^{i}}{R^{i}} \times 100(\%)
$$

式 (3) では, $R_{d}^{i}$ に対して無損傷時の水平剛性 $k$ と損傷時の水平剛性 $k_{d}$ の比（部分構造の負担寸る水平力の比）を乗じる. つまり $R_{d}^{i} の$ 分 母に用いるリファレンスとなる柱の動ひずみ応答の RMS 值に $\left(k / k_{d}\right)$ を乗じることで, 損傷時の梁と無損傷時の柱の動ひずみ応答の RMS

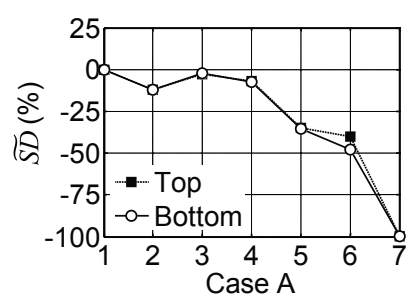

(a) P1: (A5-A7: Damage)

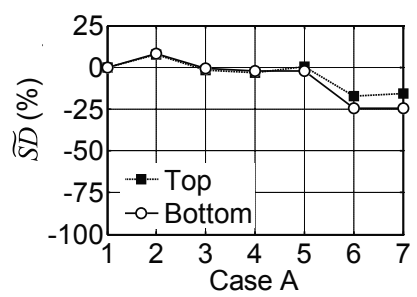

(b) P2: (Undamage)
Fig. 6 Dynamic strain reduction (No slab).

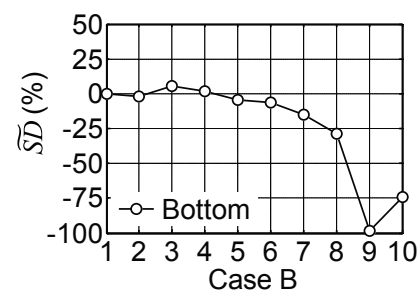

(a) P1: (Damage: B8-B10)

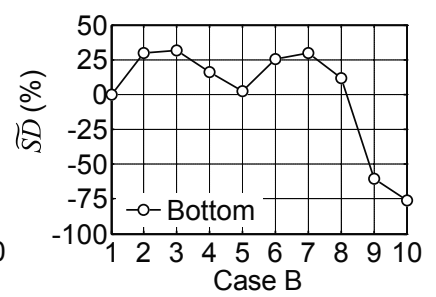

(b) P2: (Damage: B9-B10)
Fig. 7 Dynamic strain reduction (With slab).

值の比を算定する.

床スラブの有無をパラメータとした 2 体の試験体に対し, 式 (3) により動ひずみ応答の低下度 $\widetilde{S D}$ を 3.1 節に述べた手順と同様の信号 処理によって求め, 損傷の進行に伴う変化を検証した. 床スラブな し試験体における上下フランジの動ひずみ応答の低下度 $\widetilde{S D}$ の変化 を図 $6 \mathrm{a}, \mathrm{b}$ に示寸. 無損傷時に対寸る $\widetilde{S D}$ は, 梁の降伏後も大きな変 化はなく, 床スラブX軸負側の梁に破断が生じたCase A5において, センサ位置 $\mathrm{P} 1$ での梁の $\widetilde{S D}$ 急激に低下した，同位置での $\widetilde{S D}$ は破断 の進行に伴って, A5 で 35 36\%, A6 で 40\% 48\%, A7 までに $99 \%$ 以上低下し, 梁上下フランジで $\widetilde{S D} の$ 值はほぼ一致した。また, 無損 傷側 $\mathrm{P} 2$ 位置での動ひずみ応答に著しい低下は見られなかったが, A6 以降に 15 25\%程度の低下が確認された. ここでの低下は, 大変 形領域に確認されていたピン支持梁端部の面外変位に起因する梁の 剛性の低下の影響と考えられる。

次に, 床スラブ付き試験体における下フランジの動ひずみ応答の 低下度 $\widetilde{S D}$ の変化を図 $7 \mathrm{a}, \mathrm{b}$ に示寸，上フランジの動ひずみ応答は床 スラブの影響を受けるため, 破断の影響の考察には下フランジの忘 答を用いた. 下フランジの応答の計測值は, 六角スタッドとコンク リートの付着による合成効果の寄与が失われた Case B7 までに, セ ンサ位置 P1 で無損傷時から 15\%減少し, 一方 P2 の梁では, 最大 で $31 \%$ 上昇， $2 \%$ 上昇の範囲で変動を繰り返した.

一方, 鋼梁の破断が生じると動ひずみ応答の低下度は先述の結果 と同様に, 損傷の進行に伴って著しく進行した. 負側の梁に破断が 生じた B8 では P1 の $\widetilde{S D} 29 \%$ 低下し, 同位置梁下フランジとウェ ブが完全に破断した B 9 では $98 \%$ の減少率が確認できた。 B10では 損傷度が同じであるにも関わらず， $\widetilde{S D}$ の上昇が観察された。この損 傷ケースでは正側（P2）に損傷が初めて確認され, 正側の損傷に起 因して相対的に $\widetilde{S D}$ 増加したためと考えられるが, 複数の損傷の相 関についてはさらなる検討が必要である. 一方 P2 では, 全下フラ ンジが破断した B9 において $\widetilde{S D}$ は急降下し, ウェブ半分が破断した B10では, 76\%に至った。

以上の結果から，面外一の変形を固定した条件下では，動ひずみ 応答の低下度 $\widetilde{S D}$ は鋼梁の塑性化による影響は受けず, 鋼梁の破断の 
程度に応じて顕著に減少する. また, 床スラブのひび割れによる合

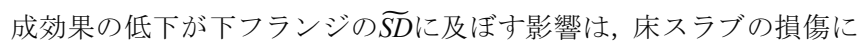
よる局所的な剛性の低下や梁せいに対する床スラブ厚など, 鋼梁と コンクリートの相対的な剛性や強度により変化すると考えられ, そ の定量的評価は今後の検討課題としたい.

\section{4 モデル更新法による耐震性能評価}

3 章で算定した損傷指標は局所的な損傷度を示寸重要な指標であ るが, 構造技術者や専門家の間で共通の理解が可能な, 直接的な（耐 震）構造性能指標ではない，そこで本章では，3 章で同定した損傷 指標に基づいて数值解析モデルに損傷を反映し, 更新した解析モデ ルを用いて構造物の残余耐震性能を定量的に評価する手法を, 新た に提案する. 具体的には, 動的中立軸位置 $N A$ の変化と動ひずみ応 答の低下度 $\widetilde{S D}$ 基づいて, 床スラブおよび鋼梁の損傷状態を部材ご とに同定し, 同定された損傷状態を再現した解析モデルの静的解析 により, 水平剛性と耐力の低下度を推定した。ささらに, これらの推 定值と準静的試験における実験值を比較することにより，一連の提 案手法における耐震性能推定の精度を検討した.

\section{1 モデル概要}

汎用構造解析コード OpenSees ${ }^{16)}$ を用い, ピン架構付き柱梁接合 部試験体の解析モデルを構築した. 図 $8 \mathrm{a}, \mathrm{b}$ に解析モデルの概要を 示寸. 解析モデルの各部材は, 試験装置及び試験体の部材寸法・部 材重量に基づいて構築した. 実験と同椂に, 両端ピン接合のトラス 材を用いて柱頂部を架構と結合し, 柱下部はピン支持, 梁端部は梁 下に剛なトラス材を配してローラー支持とした。 パネル接合部は剛 とし，パネル接合部と各梁端部の境界には長さを持たない回転バネ を扱入した，損傷の進行に応じて回転バネの岡性 $k_{c}$ を低下させ, 梁 の損傷を模擬した（詳細は 4.4 節）。また, 柱と梁の断面はファイバ 一要素でモデル化した。鋼梁は材軸方向に 10 分割し, 断面内のフ アイバー数はウェブ高さ方向に 10 , 厚さ方向に 1 , フランジ幅方向 に 1 , 厚さ方向に 4 とした. さらに, 柱断面は 9 分割し, それぞれ のファイバー数は $\mathrm{x}$ 方向に $7, \mathrm{z}$ 方向に 1 とした. 鋼材の応力ひず み関係はバイリニア型とし, 鋼のヤング係数 $E_{s}$ を $200 \mathrm{GPa}$, 材料試 験結果に基づき降伏応力 $\sigma_{y}$ を $330 \mathrm{MPa}$, ひずみ硬化を $1.0 \%$ とした. また，床スラブの有効幅は合成設計指針 15)の算定式に基づいて $388 \mathrm{~mm}$ とし, スラブ厚を六角スタッドせいに等しい $30 \mathrm{~mm}$ とした (メッシュ筋上部のかぶり厚さは耐力に寄与しないと仮定). 床スラ ブ断面のファイバー数は強軸方向に 5 , 弱軸方向に 1 とし, 大きな 曲げ引張力が加わる上部の要素から段階的に削除することで, ひび 割れによる合成効果の低下を模擬した。 コンクリートの材料特性に はPopovics モデル 17)を適用し, 初期ヤング係数 $E_{c}$ を $17.4 \mathrm{~N} / \mathrm{mm}^{2}$, 圧縮強度を 4 週強度の 0.85 倍である $13.2 \mathrm{~N} / \mathrm{mm}^{2}$, 引張強度を圧縮 強度の $1 / 10$ とした。

\section{2 モデル更新と耐震性能評価に用いる解析}

本手法は，（1）解析モデルに損傷状態を反映するモデル更新のた めの動的応答解析と，(2) 損傷状態を反映した解析モデルを用いて 残余耐震性能を評価する静的解析, の 2 段階で構成される.モデル 更新に必要なデータは, 地震前後（無損傷時と損傷時）の動ひずみ の実測データから求めた損傷指標で, 床スラブおよび鋼梁部材に損 傷を加えた解析モデルの動的応答解析から算定した損傷指標と比較
した，損傷指標の比較において，実測值との関係から設定した目的 関数の条件を満たすまで解析モデルの損傷度を変化させた．動的応 答解析では, 実験時に用いたホワイトノイズを入力波とし, サンプ リング周波数を $100 \mathrm{~Hz}$ ，計測時間を 30 秒とした．動ひずみ応答は 実験での計測位置と同じ位置で出力し (図 3 参照), 実測值と同様 の手順で信号処理を施した。次に，更新したモデルを用いて残余耐 震性能を評価する静的解析を実施した。残余耐震性能の評価項目手 法については，4.5 節及び 4.6 節に後述する.

\section{3 床スラブ損傷のモデル化}

図 9 に床スラブ合成効果のモデルの模式図を示す，上図のように 床スラブが引張力を受ける負曲げモーメントを漸増させたとき，曲 げモーメントが最大となる柱梁接合部付近から床スラブにひび割れ が生じて合成効果が低下寸ると仮定する．下図は床スラブ断面の要 素を示しており，合成効果の低下は断面要素の削除をもって表現す る. 解析モデルでは床スラブを厚さ方向に 5 段に区分し（図 $8 \mathrm{~b}$ ), 梁軸方向の各位置での損傷度を 5 段階で評価した。ここで, 解析モ デルにおける損傷の進行について, 以下の仮定を適用した. 第 1 に, 合成梁の軸方向のある位置における負曲げモーメントが初めて曲げ ひび割れモーメントに達した時に，その位置での床スラブ断面の最 外縁要素を削除寸る．曲げひび割れモーメントは，コンクリート最 外縁に初めてひび割れの生じる曲げモーメントで, コンクリート供 試体の引張割裂試験結果に基づいて, 鋼梁の全塑性モーメント $M_{p}$ の 0.2 倍とする. 第 2 に, 合成梁の軸方向のある位置における負曲 げモーメントが $M_{p}$ に達した時点で合成効果が完全に失われるとし, 床スラブ断面の全要素を削除する。なお，本稿の実験では正負繰返 し載荷を行ったため, 床スラブの損傷は柱位置に対して軸対称に進 行するものとした，上記の仮定に基づいて，床スラブの断面要素を 徐々に削除していき, 動的中立軸位置を指標として, 実測時の内力

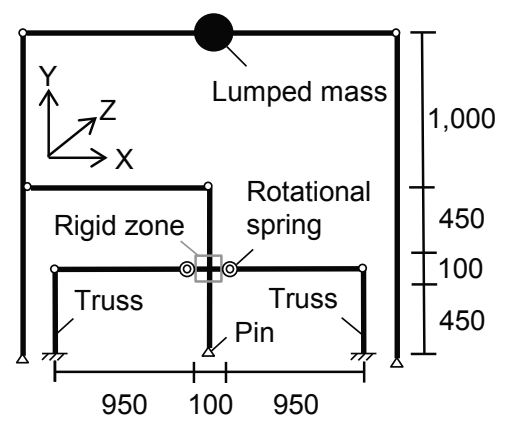

(a) Beam-column connection with frame

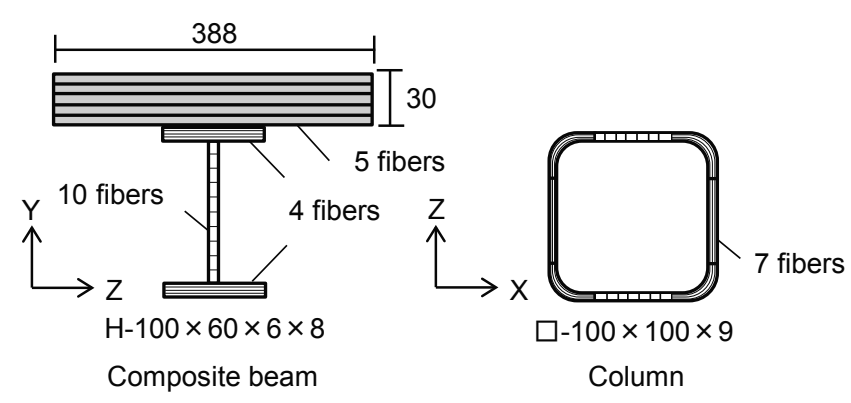

(b) Section model

Fig. 8 Analysis model. 
分布状態と最も近い損傷状態になった時点で更新を終える.

ここで, 解析モデルにおける動的中立軸の低下度 $N A^{S}$ を床スラブ の合成効果の低下によって減少する变数とし, モデル更新の目的関 数を $J\left(N A^{S}\right)$ とする. 目的関数 $J\left(N A^{S}\right)$ は, 動的中立軸低下度の 実験值 $N A^{T}$, 目的関数に対寸る閾值 $a$ を用いて式(4)で与えられる.

$$
J\left(N A^{S}\right)=\frac{N A^{T}-N A^{S}}{N A^{T}}<a
$$

合成梁床スラブ断面の分割要素を段階的に削除し, 式 (4) によ り, 動的中立軸低下度の実験值に対する解析值の誤差が設定した閾 值を満たす床スラブ断面を同定する.このとき, 閾值 $a$ を $1 \%$ とし, $\mathrm{P} 1$ 位置で計測した動的中立軸を用いて解析モデルを更新した.

\section{4 梁の破断のモデル化}

サンブナンの原理によると, 破断による鋼梁の曲げ岡性の低下は, 破断部の断面欠損に加え, 破断による固定端部拘束条件の変化に起 因する ${ }^{18)}$. 後者による剛性低下を定量化することは困難であるため, 等価長さ $L_{\text {eff }}$ に渡って断面が破断したモデルに置き換えることで簡 略化し, Sinha 等の研究 ${ }^{19)}$ に基づいて, 等価長さ $L_{\text {eff }}$ を柱幅の 0.75 倍（75mm）とした（図 10a).さらに，このモデルを梁の破断によ る回転剛性の減少分に置き換え, 式（5）により固定端部に回転バ ネ20)をもつ片持ち梁のモデルに置換することで, 梁端部に生じる破 断を模擬した。（図 10b). なお, 十字型柱梁接合部試験体の場合, 片持ち梁スパン長さ $L$ は柱梁の交差点からピンローラー支持位置ま での長さ $(1,000 \mathrm{~mm})$ とした.

$$
k_{c}=\frac{3 L^{2}}{\frac{L^{3}-\left(L-L_{e f f}\right)^{3}}{E I_{\text {frac }}}+\frac{\left(L-L_{\text {eff }}\right)^{3}-L^{3}}{E I}}
$$

梁の破断を模擬する回転バネ剛性 $k_{\mathrm{c}}$ の同定に用いられる目的関数 $J\left(k_{c}\right)$ は, 回転バネ剛性 $k_{\mathrm{c}}$ を変数とし, 動ひずみ応答の低下度の実 験值 $\widetilde{S D}^{T}$ と解析值 $\widetilde{S D}^{S}$, 目的関数に対する閾值 $a$ を用いて式 (6) で 与えられる. 目的関数 $J\left(k_{c}\right)$ を用いて, 動ひずみ応答の低下度の実 験值に対する解析值の誤差が設定した闇值を満たす最大值 $k_{\mathrm{c}}$ を求め る.

$$
J\left(k_{c}\right)=J\left(\widetilde{S D}^{S}\right)=\frac{\widetilde{S D}^{T}-\widetilde{S D}^{S}}{\widetilde{S D}^{T}}<a
$$

本論では P1 で計測した動ひずみ応答から実験值 $\widetilde{S D}^{T}$ を算定し, 閾值 $a$ を $1 \%$ として解析モデルを更新した.

\section{5 損傷同定による耐震性能評価：床スラブのひび割れ}

床スラブ付き試験体に対し， 4.2 節で述べた手法により, 合成効 果が低下した Case B1 から B7 までの耐震性能評価結果を図 11 に 示す. 動的中立軸低下度に基づいて更新された柱梁接合部の残余水 平剛性と，鋼梁の耐力に対する床スラブとの合成効果による耐力増 分の低下度を, 更新モデルの変位増分（プッシュオーバー）解析に より推定した. 残余水平剛性の推定值と解析值の誤差は B2 で最大 $10 \%$, 損傷の程度に関わらず全損傷ケースにわたり良い対応を示 した。一方, 床スラブのひび割れによる耐力増分の低下度は, 実験 では B3 から B5 にかけて中立軸は単調低下したのに対し, 耐力増 分の変化は単調ではなかったため, 耐力評価の誤差が大きく, B3 で最大 $21 \%$ でった。実際は柱梁接合部のスラブ損傷は非対称・非 線形挙動を示すが，提案する簡易ひび割れモデルにより耐震性能の 低下を推定することが可能であることが実証された。

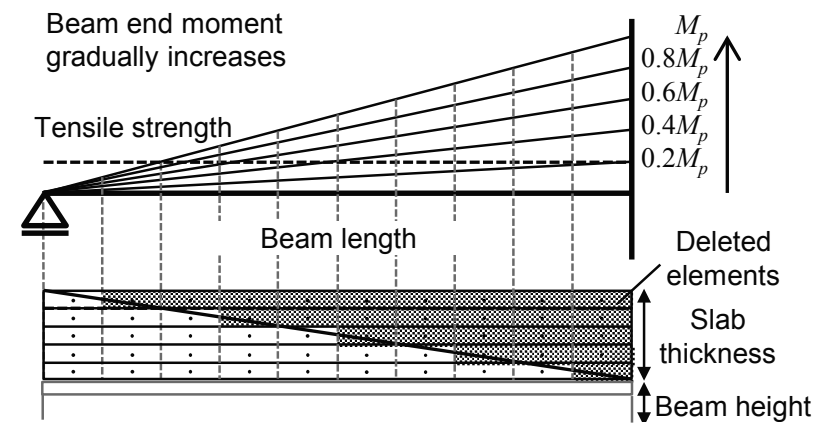

Fig. 9 Slab deterioration model.

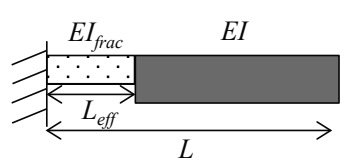

(a) Effective length model (b) Spring model

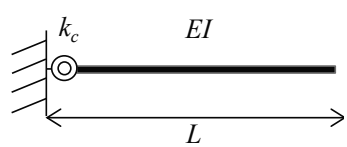

Fig. 10 Beam fracture model.

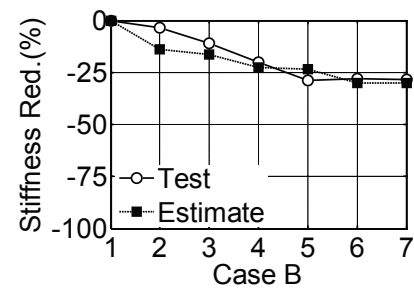

(a) Stiffness reduction

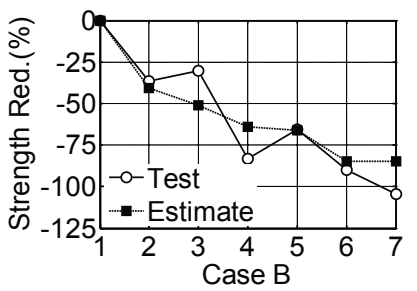

(b) Strength reduction
Fig. 11 Residual Seismic performance evaluation (With slab).

\section{6 損傷同定による耐震性能評価：鋼梁の破断}

鋼梁の破断は，床スラブによる合成効果の寄与がほぼ完全に失わ れた後に始まるという前章の実験結果に基づいて, 床スラブなし試 験体に対して，鋼梁の損傷同定による耐震性能評価を試みた。セン サ位置 $\mathrm{P} 1$ 側の鋼梁に破断が生じた損傷ケース A5 A7 を局所損傷同 定の対象とし，モデル更新後の残余耐震性能（水平剛性，破断部の 断面量，最大耐力）を実験值と比較した。ただし終局状態にある A7 では安全上の理由から載荷は行っておらず，水平剛性は最終サイク ルの除荷剛性により評価し，最大耐力は評価していない.

モデル更新後の水平剛性は, 梁端部の回転バネ剛性の低下度から 算定し，準静的載荷試験の結果と比較した。同時に，更新した回転 バネ剛性の低下度から式 (5)を用いて破断部の断面量 $I_{\text {frac }}$ を推定し, 目視による実測值と比較した。さらに，推定した破断部の断面量に 基づき，最大耐力の低下度を推定した。

図 $12 \mathrm{a}-\mathrm{c}$ に示寸推定值と実験值との誤差は，いずれの評価項目に おいても最大で $15 \%$ 22\%と，動ひずみ応答の低下度に立脚した損 傷バネモデルの損傷度との対応性が実証された．水平剛性と最大耐 力の推定值は実験值を上回る傾向にあり，準静的載荷時に確認され た面外座屈（層間変形角で最大 $2.8 \%$ ）による水平剛性・耐力の低下 や，微振動時に接触した破断部が圧縮側に抵抗していたことに起因 する可能性がある．断面量の推定では，破断量が小さいときに，解 析における推定值が破断量を過大に評価寸る傾向が見られた。急激 な破断の進行により設定した損傷ケースが少なく，データがそしい ため, 計測誤差や目視実測における誤差を多分に含む可能性がある. 


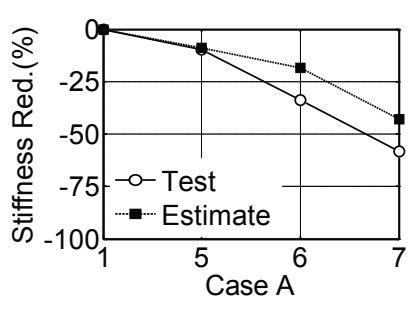

(a) Stiffness reduction

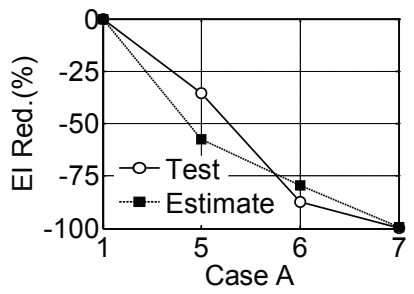

(b) El reduction

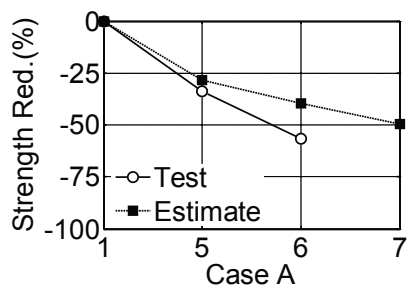

(c) Strength reduction

Fig. 12 Residual Seismic performance evaluation (No slab).

以上，合成梁に生じた床スラブのひび割れと鋼梁の破断を，簡易 モデルを用いて個別に評価することにより，合成効果の低下と鋼梁 の破断の進行度を定量化し, 残余耐震性能として評価することがで きた。 今回評価対象とした損傷ケースの母数が少なく, これらの結 果は, 計測誤差 (計測機器, ひび割れ・破断の目視実測) および振 動試験下と準静的載荷下での試験体状態の相違（ひび割れや破断の 開閉など), 損傷度が小さい場合の損傷同定限界, モデルと試験体間 の相違などの要因を含むため, それらの要因と推定精度の相関につ いては，今後の検討が必要である。

\section{5 結論}

床スラブ付き柱梁接合部を対象に, 床スラブのひび割れに起因す る合成効果の低下と, 鋼梁の破断を定量化する手法を考案し, 微動 下の中層建物の柱梁接合部の固有モード応答を簡易に再現する実験 装置により，地震時に合成梁に生じる損傷を検証した。さらに，内 力分布変化から同定した局所損傷に立脚するモデル更新法を用いた 残余耐震性能評価を試みた。得られた知見を以下にまとめる.

1. 床スラブのひび割れに伴う合成効果の低下によって, 梁断面 の中立軸が変遷することを確認した，動ひずみ応答による中立軸は， 繰返し載荷下の正曲げ・負曲げ時の中立軸の平均值にほぼ一致した.

2. 鋼梁の破断に伴い, 下フランジの動ひずみ RMS 值が低下す ることを確認した. 動ひずみ RMS 值は, 断面の欠損のみならず, 床スラブ損傷や複数損傷の影響を受けることがわかった.

3. 微振動下の中立軸位置の変化を目的関数としたモデル更新に より, 曲げモーメント分布に基づくひび割れ進行を再現した簡易モ デルで中立軸位置を同定し, 合成効果の低下に起因する水平剛性と 耐力劣化を定量的に評価した.

4. 動ひずみ応答の低下度を目的関数としたモデル更新により, 梁端部に生じた地震損傷を, 損傷バネモデルで同定し, 鋼梁の破断 に起因する水平剛性と耐力劣化を定量的に評価した.

今後は, 複数損傷や床スラブ損傷が損傷指標に及ぼ寸影響及び残 余耐震性能評価結果の誤差・影響因子の定量化を図り, 柱梁接合部 から建物全体モデルへの応用・拡張を目指したい.

\section{謝辞}

本研究の一部は科研費 (26820230) および文部科学省委託研究「都 市の脆弱性が引き起こす激甚災害の軽減化プロジェクト (2)都市機 能の維持・回復に関する調查研究」の助成を受けた，研究を進める にあたり, 北京工業大学の唐貞云氏と京都大学工学研究科の李小華 氏に多大なご協力をいただいた。ここに記して謝意を表する.

\section{参考文献}

1）一般財団法人日本建築防災協会: 被災建築物応急危険度判定 $O Q$ 通信, 第 15 号, 2013.2 .

2）文部科学省研究開発局, 京都大学防災研究所 : 都市の脆弱性が引き起 こす激甚災害の軽減化プロジェクト 都市機能の維持・回復に関する調 查研究 平成 25 年度成果報告書, 2014 .

3）倉田真宏, 峰岸楓, 唐貞云, 中島正愛 : 合成梁を有する鋼構造柱梁接 合部の繰返し載荷による振動特性の変化, 日本建築学会構造系論文集, 第 703 号, pp.1271-1278，2014.9.

4) Ji, X., Fenves, G. L., Kajiwara, K., and Nakashima, M.: Seismic Damage Detection of a Full-Scale Shaking Table Test Structure, $J$. Struct. Eng., ASCE, Vol.137, No.1, pp.14-21, 2012.

5) Vanik, M. W., Beck, J. L., and Au, S. K.: Bayesian Probabilistic Approach to Structural Health Monitoring, J. Eng. Mech.,_Vol.126, No.7, pp.738-745, 2000.

6) 山口真矢子, 倉田真宏, 宮澤理稔，野澤貴：鋼構造骨組の損傷度と伝 播波の到達遅延 微動記録一の地震波干渉法の適用, 構造工学論文集, Vol.60B, pp.281-288, 2014.3.

7) 濱本卓司, 森田高市, 勅使川原正臣 : 複数モードの固有振動数変化を 用いた多層建築物の層損傷検出，日本建築学会構造系論文集，第 560 号, pp.93-100, 2002.10.

8）楠浩一, 勅使川原正臣：リアルタイム残余耐震性能判定装置の開発の ための加速度積分法, 日本建築学会構造系論文集, 第 569 号, pp.119-126, 2003.7.

9) Sohn, H., and Law, K.H.: A Bayesian Probabilistic Approach for Structure Damage Detection, Earth. Eng. Struct. Dyn., Vol.26, No.12, pp.1259-1281, 1997.

10) Kurata, M., Li, X., Fujita, K., Yamaguchi, M.: Piezoelectric Dynamic Strain Monitoring for Detecting Local Seismic Damage in Steel Buildings, Smart Mat. Struct., Vol.22, No.11, 115002, 2013.

11) Li, X., Kurata, M., Nakashima, M.: Evaluating Damage Extent of Fractured Beams in Steel Moment-Resisting Frames Using Dynamic Strain Responses, Earth. Eng. Struct. Dyn., pp. 563-581, 2015.

12) Dorvash, S., Pakzad, S.N., Labuz, E.L., Ricles, J.M., and Hodgson, I.C.: Localized Damage Detection Algorithm and Implementation on a Large-Scale Steel Beam-to-Column Moment Connection, Earth. Spectra., 2014.

13) Yao, G., Chang, K., and Lee, G.: Damage Diagnosis of Steel Frames Using Vibrational Signature Analysis, J. Eng. Mech., Vol.118, No.9, pp.1949-1961, 1992.

14) Sigurdardottir, D. H., and Glisic, B.: Neutral Axis as Damage Sensitive Feature, Smart Mat. Struct. Vol.22, No.7, 075030, 2013.

15）日本建築学会：各種合成構造設計指針・同解説，丸善，2001，新增補 版 2012.

16) McKenna, F., Fenves, G. L., Scott, M. H., and Jeremic, B.: Open System for Earthquake Engineering Simulation (OpenSees). PEER, UC Berkeley, CA, 2000.

17) Mander, J. B., Priestley, M. J. N., and Park, R.: Theoretical Stress-Strain Model for Confined Concrete, J. Struct. Eng., ASCE, Vol.114, No.8, pp.1804-1825, 1998.

18) Horgan, C. O., and Simmonds, J. G.: Saint-Venant End Effects in Composite Structures, Composites Eng., Vol.4, No.3, pp.279-286, 1994.

19) Sinha, J. K., Friswell, M. I., and Edwards, S.: Simplified Models for the Location of Cracks in Beam Structures Using Measured Vibration Data, J. Sound Vib., Vol.251, No.1, pp.13-38, 2002.

20）濱本卓司，井上了太：並列モデル同定を用いた多層建築物の部材損傷 検出, 日本建築学会構造系論文集, 第 655 号, pp. 1661-1670, 2010.9. 


\title{
INTEGRITY ASSESSMENT OF STEEL BEAM-COLUMN CONNECTIONS USING AMBIENT-BASED INNER-FORCE ESTIMATES
}

\author{
Masahiro KURATA*, Akiko SUZUKI**, Kaede MINEGISHI*** \\ and Masayoshi NAKASHIMA**** \\ * Assoc. Prof., Ph.D., DPRI, Kyoto Univ. \\ ** Grad. Stud. Researcher, Dept of Archi and Archi.Eng., Kyoto Univ. \\ ** JGC Corporation \\ **** Prof., Ph.D., DPRI, Kyoto Univ
}

In responses to recent large earthquakes and their consequences, post-earthquake damage assessment of buildings has drawn much attention for reducing earthquake impacts on our society. A lack of information on the status of buildings (i.e., damage level or residual performance) may significantly delay decision-making on evacuation or re-occupancy. At the present moment, however, standard visual-based inspection procedures require considerable labors and time.

This paper presents a method of evaluating local damage in steel beam-column connections using dynamic strain responses measured under ambient vibrations. In developing the method, particular emphasis was on providing damage information in the format familiar to structural engineers and stakeholders. In the presented method, inner-force distribution in steel beam-column connection was estimated using the natural modal components of ambient vibration responses measured by PolyVinylidene DiFluoride (PVDF) strain sensors. For evaluating damage in steel beam-column connections, two kinds of damage-related features were proposed. One was the transition of the neutral axis for evaluating the loss of composite action between steel beams and concrete floor slab. The neutral axis was estimated from the ratio of dynamic strain responses at the bottom and top flange. The other was the reduction of the dynamic strain responses from the undamaged condition in terms of root mean square (RMS) for quantifying steel beam fractures. The reduction of RMS can be translated into the reduction of the second moment of inertia at the fractured section using a pre-defined damage curve.

A unique testing method was developed to verify the damage-related features at component-level. In the proposed test configuration, a specimen of building's components is connected with a pinned frame that supports large fictitious mass so that the natural frequency of the entire system becomes similar to that of the building. The entire system is loaded quasi-statically to introduce seismic damage to the specimen and, as notable damage occurs, the natural modal vibration is excited using a modal shaker.

Two specimens of steel beam-column connections with and without slab were tested. The tests verified the effectiveness of the proposed damage-related features in identifying the damage states: (1) the dynamic neutral axis computed by the RMS ratios of dynamic strain responses traced well the shifts of the static neutral axis and the loss of the composite action; (2) fractures at beam ends were successfully quantified by comparing the dynamic strain responses at undamaged and damage conditions.

Moreover, an analysis model of the specimen with fiber beam elements was built and whose properties were updated using the dynamic strain responses measured in the tests. In the model, the loss of composite action was represented by gradually eliminating the elements of the floor slab section until the neutral axis of the model and the measurement matched with sufficiently small error. For beam fracture, the rotational stiffness of a damage spring installed at the beam ends were updated in a similar manner. This model-updating method was particularly interested as it provided estimates on the residual seismic capacities of the specimens in terms of the quantities familiar to structural engineers (i.e., stiffness and strength). The estimated residual lateral stiffness and strength of the specimen corresponded well to those identified in the force-drift relationship with reasonable accuracy. 